\title{
Mineralogical and geochemical characterisation of open-air tailing and waste-rock dumps from the Libiola Fe-Cu sulphide mine (Eastern Liguria, Italy)
}

\author{
P. Marescotti - C. Carbone $\cdot$ L. De Capitani $\cdot$ \\ G. Grieco - G. Lucchetti · D. Servida
}

Received: 31 January 2007/Accepted: 18 April 2007

(C) Springer-Verlag 2007

\begin{abstract}
Active acid mine drainage (AMD) processes at the Libiola $\mathrm{Fe}-\mathrm{Cu}$ sulphides mine are mainly triggered by water-rock interaction occurring within open-air tailing and waste-rock dumps. These processes are mainly controlled by exposure to weathering agents, the grain size of the dumped materials, and by the quantity of sulphides, the sulphide types, and their mode of occurrence. Due to these factors, several paragenetic stages of evolution have been recognised at different depths at different sites and within the same site. The dump samples were investigated with mineralogical (reflected- and transmitted-light optical microscopy, XRPD, and SEM-EDS) and geochemical (ICP-AES, Leco) techniques. The AMD evaluation of the tailing and waste-rock samples was performed by calculating the Maximum Potential Acidity, the Acid Neutralising Capacity, (and the Net Acid Producing Potential. The results allowed us to demonstrate that the open-air tailings had already superseded their AMD apex and are now practically inert material composed mainly of stable goethite \pm lepidocrocite \pm hematite assemblages. On the contrary, the sulphide-rich waste rocks still have a strong potential to produce long term AMD, causing the acidification of circulating waters and the release of several hazardous elements.
\end{abstract}

P. Marescotti $(\bowtie) \cdot$ C. Carbone · G. Lucchetti

Dipartimento per lo Studio del Territorio e delle sue Risorse

(DIP.TE.RIS.), Genova University, C.so Europa 26,

16132 Genoa, Italy

e-mail: marescot@dipteris.unige.it

L. De Capitani · G. Grieco · D. Servida

Dipartimento di Scienze della Terra "Ardito Desio",

Milano University, Via Botticelli 23, 20133 Milan, Italy
Keywords AMD - Sulphides oxidation - Waste dumps · Tailing dumps $\cdot$ Libiola mine

\section{Introduction}

The Libiola $\mathrm{Fe}-\mathrm{Cu}$ sulphide mine was one of the most important Italian ore deposits. It was extensively exploited from 1864 until 1962 and produced over $1 \mathrm{Mt}$ of $\mathrm{Fe}-\mathrm{Cu}$ sulphides with an average grade ranging from 7 to $14 \mathrm{Cu}$ $\mathrm{wt} \%$. The mine site is located about $8 \mathrm{~km} \mathrm{NE}$ of Sestri Levante (Eastern Liguria, Italy) and extends over an area of about $4 \mathrm{~km}^{2}$ within the basin of the Gromolo Creek (Fig. 1).

The Gromolo Creek begins at 910 masl (Monte Roccagrande) and flows for almost $9 \mathrm{~km}$ to its mouths, located in the bay of Sestri Levante. It has a catchment basin of about $26 \mathrm{~km}^{2}$, with slopes varying from $2.5 \%$ to about $15 \%$. The climate is Mediterranean humid and is characterised by an average temperature of $15^{\circ} \mathrm{C}$ and rainfall that varies between 1,100 and $1,600 \mathrm{~mm} /$ year. The rainfall distribution is unimodal, with a maximum in November (over $180 \mathrm{~mm}$ ) and a dry season in summer (Provincia di Genova 2002). In the alluvial plain, the Gromolo Creek receives acid and polluted waters from two main tributaries (the Rio Boeno and Rio Cattan) that collect most of the Libiola mine waters.

As highlighted in the geological sketch (Fig. 1), the entire mining area falls within the Jurassic ophiolites of the Northern Apennines (Vara Supergroup-Abbate et al. 1980) and is mainly characterised by pillow basalts with minor serpentinites, gabbros, and ophiolitic breccias.

The sulphide ores (pyrite-rich and chalcopyrite-rich mineralisations) mainly occur as massive lenses (25$35 \mathrm{wt} \%$ sulphides) and stockwork-like epigenetic veins 
Fig. 1 Geological map of the Libiola mine area (adapted from Abbate et al. 1980, modified)

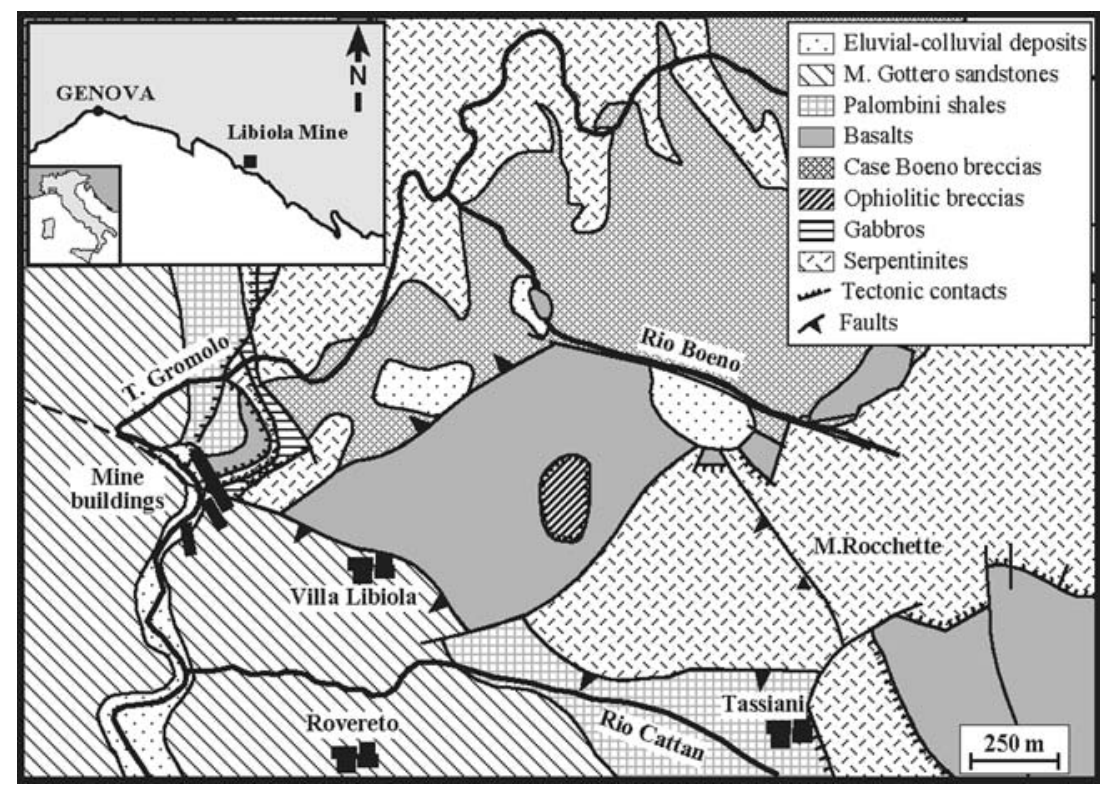

( $<10 \%$ sulphides; Garuti and Zaccarini 2005) near the top of the pillow basalt sequence. Moreover, disseminated pyrite mineralisations occur in both the pillow basalts and serpentinites. The sulphide ores are the result of a polyphasic evolution that comprised a hydrothermal oceanic stage followed by tectono-metamorphic processes that produced recrystallisation and thickening of the primary mineralisations (Ferrario and Garuti 1980).

The mining area comprises over $30 \mathrm{~km}$ of underground excavations and two open pits. Mine wastes were dumped in five major piles scattered throughout the mining area and in several minor tailing and waste-rock dumps, mainly located close to the main mine adits (Fig. 2). None of the tailings produced during the mining operations were deposited in an aqueous milieu (i.e. within natural or artificial impoundments) but in several relatively small openair dumps.

Nowadays, the Libiola mine is completely abandoned and presents serious environmental problems due to supergenic sulphide oxidation, erosion of waste deposits, inducing several types of landslides (rockslides, debris avalanches, slumps, etc.), and easily accessible mine adits, which continuously discharge strong acid waters and, sometimes, toxic gases (Marescotti and Carbone 2003).

The supergenic sulphide oxidation, internationally known as acid mine drainage (AMD) (Jambor and Blowes 1994 and references therein; Jambor and Blowes 1998; Jambor et al. 2000; Jambor 2003), is by far the most critical hazard presented by the Libiola mine area. In fact, the diffuse oxidation of sulphide minerals causes the acidification of effluents, the release of heavy metals and other pollutants, and the precipitation of huge quantities of iron-bearing muds into streambeds.
Recent geochemical analyses (Dinelli et al. 1999, 2001; Dinelli and Tateo 2002; Marini et al. 2003; Accornero et al. 2005) have shown that the waters circulating in the Libiola mine area and discharging in the catchment basin of the Gromolo Creek are strongly polluted, being characterised by a $\mathrm{pH}$ as low as 2.4 and by a dangerous quantity of heavy- and transition-metals $(\mathrm{Cr}$ 0.02-2.54 mg/l; Fe 0.03-1115 mg/l; Co 0.018-4.14 mg/l; Ni 0.1-7.78 mg/l; Cu 0.01-221 mg/l; Zn 0.1-55.9 mg/l), and sulphate (57.4-9570 mg/l). Moreover, extensive precipitation of $\mathrm{Fe}$ (III)-bearing muds is taking place throughout the whole area as a result of the mixing of acid mine-waters with local streams and ground waters (Dinelli and Tateo 2002; Marescotti and Carbone 2003; Marini et al. 2003).

The sources of the pollution are mainly represented by (1) sulphide-bearing fragments deposited in tailing and waste-rock dumps, (2) mineralised waste rocks left underground to fill voids and provide support for the excavations, and (3) unexploited surface and underground mineralised bodies.

This paper reports the results of mineralogical and geochemical research undertaken at one of the most representative waste-rock and tailing dumps, containing both excavation wastes and the remnants of ore-processing works, in the northern part of the Libiola mine area (Fig. 2), in order to determine the mineralogical and geochemical nature of the waste rocks and tailings and to understand their role in the generation of acids and the release of pollutants during AMD processes.

In particular, the AMD process was quantified using a procedure based on the AMIRA report (IWRI and EGI 2002) and the main mineralogical and geochemical 


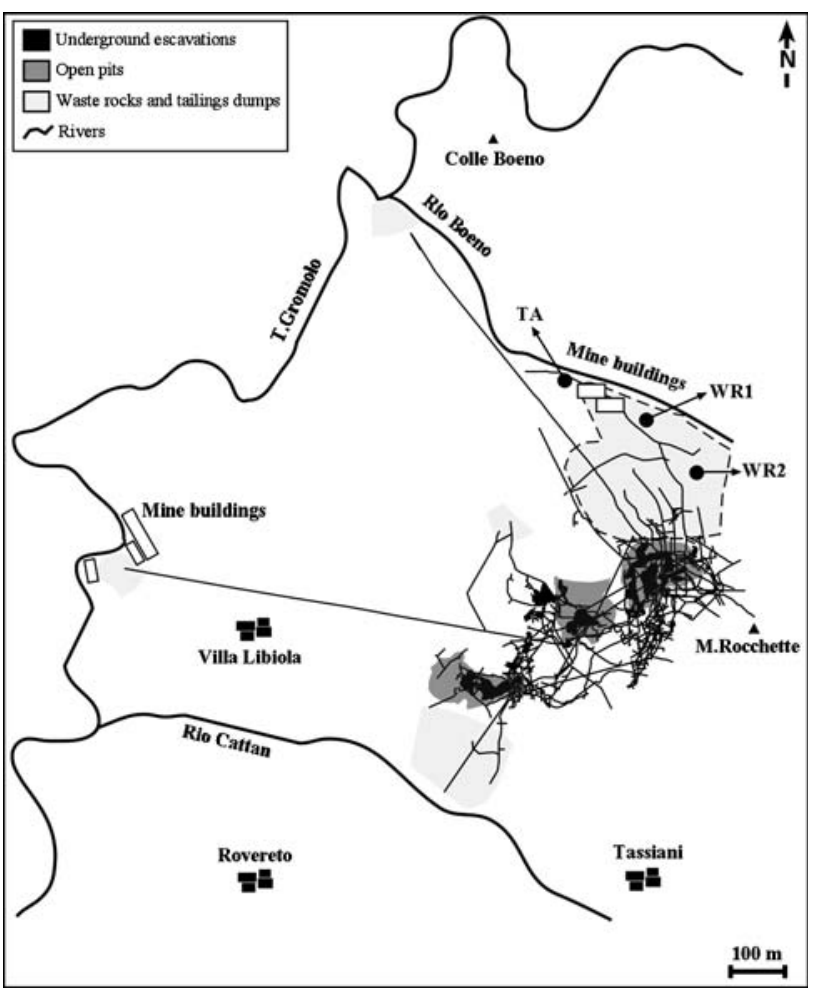

Fig. 2 Schematic sketch of the Libiola mine area (adapted from Marescotti and Carbone 2003, modified). The broken line delineates the sampling area. The three sampling sites are marked with the same abbreviations used in the text (TA,WR1, and WR2)

parameters and factors that influence the AMD and hence the quality of seepage from the dumps were investigated.

\section{Sampling strategy}

The first sampling site (hereafter named WR) is one of the biggest waste-rock piles of the entire mine area. It is an unconfined waste rock dump placed on the left side of the Rio Boeno, about $45 \mathrm{~m}$ in height and about $100 \mathrm{~m}$ in length, with a steep wall slope of about 50-70\% (Fig. 3). A study of historical documents revealed that the dump was formed over a period of about 100 years by the dumping, in a vertical sequence, of both non-valuable mineralisations (i.e. low-Cu pyrite-bearing mineralisations) and non-mineralised rocks, coming from both underground and open-pit excavations. Field observations demonstrated the notable variability of the deposited material and the presence, on the exposed vertical sections, of decimetric to metric layering marked by the alternation of fine and coarse layers and/or by variations in lithology. Significant enrichments of mineralised clasts were clearly recognisable at the bottom of the dump and at several levels close to mine adits. The overall dump is ligthly cemented by ochreous to

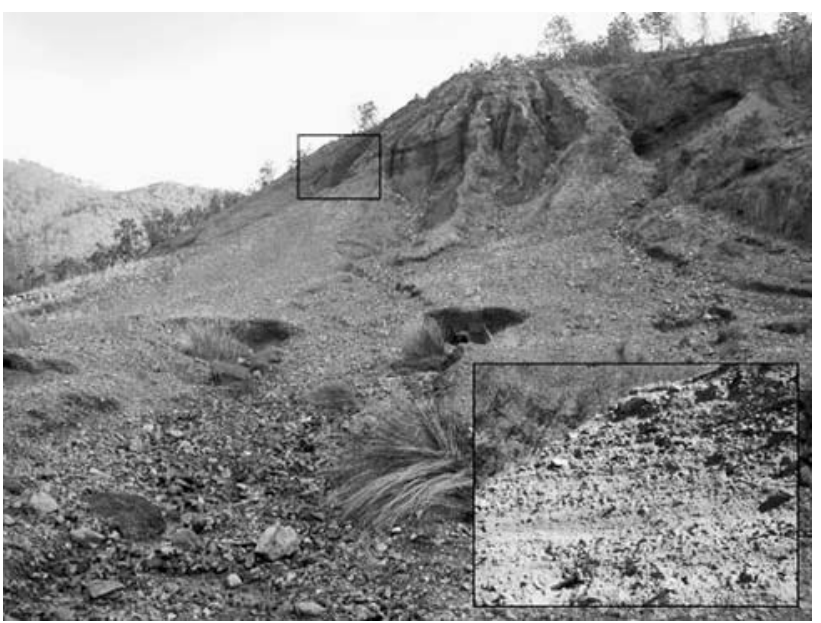

Fig. 3 Scenic view of the sampled waste-rock dump (WR); the black square indicates the WR2 sampling area, which is also magnified in the inset

reddish $\mathrm{Fe}(\mathrm{III})$ precipitates that fill interstices and cover the exposed surfaces. The parts of the dump characterised by sulphide enrichments are covered by centimetric to decimetric reddish to dark brown hardpan. For this reason, we sampled two different vertical sections of about $1 \mathrm{~m}$ outcropping in well-exposed vertical cuts at the bottom (WR1) and at the top (WR2) of the dump (Fig. 3).

The second sampling site (hereafter named TA) is a small and well-defined open-air tailing dump. It is located at the bottom of the WR pile and occurs as an elongated, flat body (about $10 \mathrm{~m}$ in length and $1 \mathrm{~m}$ in height) lying adjacent to a small stream collecting waters from some mine adits (Fig. 4). The deposited material has a gravelsand particle size and comes from preliminary mineral

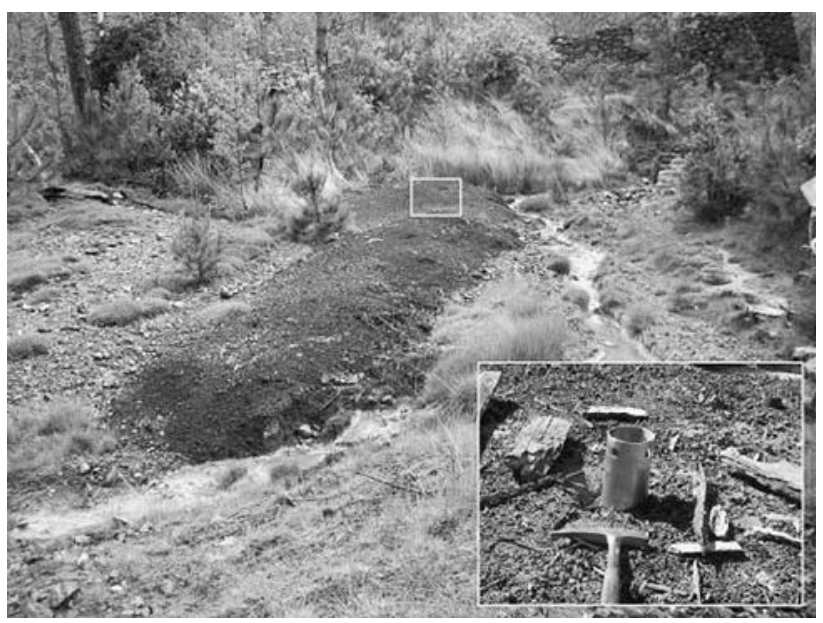

Fig. 4 Scenic view of the sampled tailing dump (TA); the white square and inset show the sampling area of the TA1 core 
processing operations (both jigging and handpicking). The dump is lightly cemented except for the surficial part, which is characterised by a centimetric to decimetric brownish-red hardpan. Metallic shavings, used to separate copper from the leach solutions circulating in the adjoining stream, occur throughout the dump. Two cores, hereafter called TA1 and TA2 $(10 \mathrm{~cm}$ in diameter and about $60 \mathrm{~cm}$ in length), were collected from the two extreme ends of the dump, using a metallic cylinder (Fig. 4).

\section{Analytical methods}

Thirteen samples (WR and TA) were divided into two identical aliquots for mineralogical and geochemical analyses performed at the Dipartimento per lo Studio del Territorio e delle sue Risorse (Genova University) and Dipartimento di Scienze della Terra “A. Desio" (Milano University), respectively.

The mineralogy of the samples was determined using several techniques that included optical (binocular, transmitted-, and reflected-light) microscopy, X-ray powder diffraction (XRPD), scanning electron microscopy (SEM) with microanalysis (EDS), and grain size analyses.

The particle size distribution was obtained by wet sieving the samples with a Controls D411 Automatic Sieve Shaker into size fractions of $>64 \mathrm{~mm}, 32-64 \mathrm{~mm}, 16-$ $32 \mathrm{~mm}, 8-16 \mathrm{~mm}, 4-8 \mathrm{~mm}, 1-4 \mathrm{~mm}, 355 \mu \mathrm{m}$ to $1 \mathrm{~mm}$, 150-355 $\mu \mathrm{m}, 125-150 \mu \mathrm{m}, 106-125 \mu \mathrm{m}, 75-106 \mu \mathrm{m}$, and 53-75 $\mu \mathrm{m}$. The suspended material passing through the 53$\mu \mathrm{m}$ sieve was collected and filtered with a paper filter (16 $\mu \mathrm{m}$ diameter). All the fractions were successively dried at room temperature and weighed.

The 150-355 $\mu \mathrm{m}$ fraction was embedded in epoxy resin and then prepared for standard polished thin sections for optical and electron microscopy analyses. The 53-75 $\mu \mathrm{m}$ and $16-53 \mu \mathrm{m}$ fractions were chosen for mineralogical determinations with XRD.

Optical and electron microscopy were performed to characterise the main lithotypes and mineral species with particular regard to the sulphide species, their degree and style of alteration. Moreover, the modal abundance of the sulphide mineralisation, non-mineralised rocks and alteration products was established by point counting (based on 500 counts per section) using an optical microscope (reflected and transmitted light).

The mineral chemistry was determined by routine microanalysis on polished metallographic slides using a Philips SEM 515 equipped with an EDS spectrometer, at $15 \mathrm{kV}$ accelerating voltage, $2-15 \mathrm{nA}$ beam current, and $10-25 \mu \mathrm{m}$ beam diameter. Counting times were set at $60 \mathrm{~s}$ to prevent damage to the coated surface. Calibration was accomplished with a set of synthetic and natural standards for the elements reported in brackets: natural pargasite and $\mathrm{K}$-augite ( $\mathrm{Si}, \mathrm{Al}, \mathrm{Na}, \mathrm{Mg}, \mathrm{K}, \mathrm{Ca}$ ), ilmenite ( $\mathrm{Ti}, \mathrm{Mn}$ ), chromite $(\mathrm{Cr})$, apatite $(\mathrm{P})$, barite $(\mathrm{S})$, hematite and olivine $(\mathrm{Fe})$, heazlewoodite $(\mathrm{Ni})$, chalcopyrite $(\mathrm{Cu})$, and metals $(\mathrm{Cu}, \mathrm{Co}, \mathrm{Zn}, \mathrm{Pb}, \mathrm{Sb})$.

The XRPD analyses were carried out using a Philips PW3710 diffractometer equipped with a Co-anode ( $\mathrm{CoK} \alpha$ radiation; current $20 \mathrm{~mA}$, voltage $40 \mathrm{kV}$ ) and interfaced with PC-APD software for data acquisition and processing. Phase identification of the $53-75 \mu \mathrm{m}$ fraction was performed under the following conditions: range $5-120^{\circ} 2 \theta$; step $0.020^{\circ} 2 \theta$, sampling time $10 \mathrm{~s}$.

Due to the low crystallinity of the secondary minerals, the $16-53 \mu \mathrm{m}$ fraction was analysed with a total acquisition time of $\sim 8 \mathrm{~h}$, thus improving the peak-to-noise ratio: XRD patterns were obtained in the range $5-120^{\circ} 2 \theta$, step size $0.030^{\circ} 2 \theta$, counting $5.5 \mathrm{~s}$ per step.

The bulk-element composition of each sample was assessed by acid digestion $(0.5 \mathrm{~g}$ powder leached with $3 \mathrm{ml}$ 2-2-2 $\mathrm{HCl}-\mathrm{HNO}_{3}-\mathrm{H}_{2} \mathrm{O}$ at $95^{\circ} \mathrm{C}$ for $1 \mathrm{~h}$ ) followed by ICPAES analysis at the ACME Laboratory.

The copper concentration was determined by acid digestion $(0.25 \mathrm{~g}$ powder leached with $6 \mathrm{ml} \mathrm{HCl} \mathrm{30 \%} \mathrm{Suprapur}$ and $2 \mathrm{ml} \mathrm{HNO}_{3} 65 \%$ Suprapur) in a closed microwave oven (Milestone, 1200 Mega), followed by ICP-AES. The total S and $\mathrm{C}$ were determined by Leco analysis at the ACME Laboratory.

The AMD evaluation of tailing and waste-rock samples was based on the "AMIRA P387A Project: Prediction and kinetic control of AMD"' procedure (IWRI and EGI 2002) which is a revision of the Sobek procedure (Sobek et al. 1978).

Each sample was dried in an oven at $70^{\circ} \mathrm{C}$ for $5-6 \mathrm{~h}$ and divided into two portions, one of which was archived for further studies and the other pulverised in an agate planetary mill to a grain size $<0.063 \mathrm{~mm}$, homogenised, and divided again into two sub-samples.

The ABA values (Acid-Base Account that involves static laboratory procedures that evaluate the balance between acid-generating and acid-neutralising processes) are referred to as the Maximum Potential Acidity (MPA) and the Acid Neutralising Capacity (ANC), respectively.

Maximum Potential Acidity is an estimate of the amount of acid that the sample can release through the complete reaction of sulphides, expressed as $\mathrm{H}_{2} \mathrm{SO}_{4} \mathrm{~kg} / \mathrm{t}$. The evaluation of MPA by the AMIRA standard procedure is based on the conservative assumption that all $\mathrm{S}$ is present as pyrite. This simplification may overestimate the AMD as other sulphides with higher Me:S ratios have lower acid generation potentials than pyrite. Moreover, such an overestimation is strongly emphasised and can give unrealistic results where high portions of $\mathrm{S}$ are present as nonacid generating phases (i.e. sulphates). For this reason, in 
addition to the standard MPA assessment using total S, a second MPA value was calculated for each sample using sulphide $\mathrm{S}$ instead of total $\mathrm{S}$. ANC is an estimate of the buffering capacity of the sample expressed as $\mathrm{H}_{2} \mathrm{SO}_{4} \mathrm{~kg} / \mathrm{t}$ that the sample is able to neutralise. It was experimentally determined by titration preceded by a "fizz test'" as in Sobek et al. (1978).

The difference between the MPA and ANC is referred to as the Net Acid Producing Potential (NAPP). NAPP is a theoretical calculation commonly used to indicate whether a material has potential to generate AMD. It represents the balance between the capacity of a sample to generate acid (MPA) or neutralise acid (ANC). The NAPP is also expressed in units of $\mathrm{kg} \mathrm{H}_{2} \mathrm{SO}_{4} / \mathrm{t}$ and when it is negative indicates that the sample may have sufficient ANC to prevent acid generation. Conversely, if the NAPP is positive it indicates that the material may be acid generating.

\section{Mineralogical characterisation}

\section{Particle size distribution}

The tailing samples (TA1-2) showed a similar particle size distribution with a wide range of particle sizes, especially for the gravely and sandy fractions (Fig. 5). The 53-16 $\mu \mathrm{m}$ fraction was $<5 \mathrm{wt} \%$. This particle size distribution was anomalous for a classic tailing dump, which is normally dominated by sandy and silty material and characterised by a narrow particle size range.

The WR1 and WR2 samples were quite different in terms of their mean grain sizes and size distribution
(Fig. 5). WR1 was gravel-dominated and showed a relatively uniform particle size distribution in the range 2$64 \mathrm{~mm}$, whereas the sandy and silty fractions $(<13 \mathrm{wt} \%)$ were quite well sorted. WR2 was gravely-sandy waste with a wide particle size range of 0.05-64 mm. Moreover, unlike WR1, the silty fraction was an important component, representing about $12 \mathrm{wt} \%$ of the total.

\section{Mineralogy of the dumped material}

The analyses performed on the $16-53 \mu \mathrm{m}, 53-75 \mu \mathrm{m}$, and 150-355 $\mu \mathrm{m}$ fractions allowed us to obtain the mineralogy and the mineral chemistry of the material deposited in both the tailings and waste-rock dumps.

To discriminate between reagents and reaction products and to correlate the mineralogical data with the geochemical results, the primary minerals and authigenic phases formed through the AMD processes were subdivided into two groups on the basis of the scheme of Jambor and Owens (1993) for tailing-mineral identification: (1) primary minerals (i.e. those minerals that constituted the ore and gangue assemblages and that were originally deposited within the waste dumps); (2) secondary minerals (i.e. those minerals that formed within the dumps by precipitation from metal-rich waters, derived from the AMD processes). Since the tailing and waste-rock dumps studied were openair deposits, tertiary and quaternary minerals of the Jambor and Owens (1993) classification could not be distinguished. For this reason, the surface blooms recognised at the surface of the WR dump (see below) were considered as secondary minerals, because they were an effective part of the overall deposit environment.
Fig. 5 Particle size distribution of the WR and TA samples

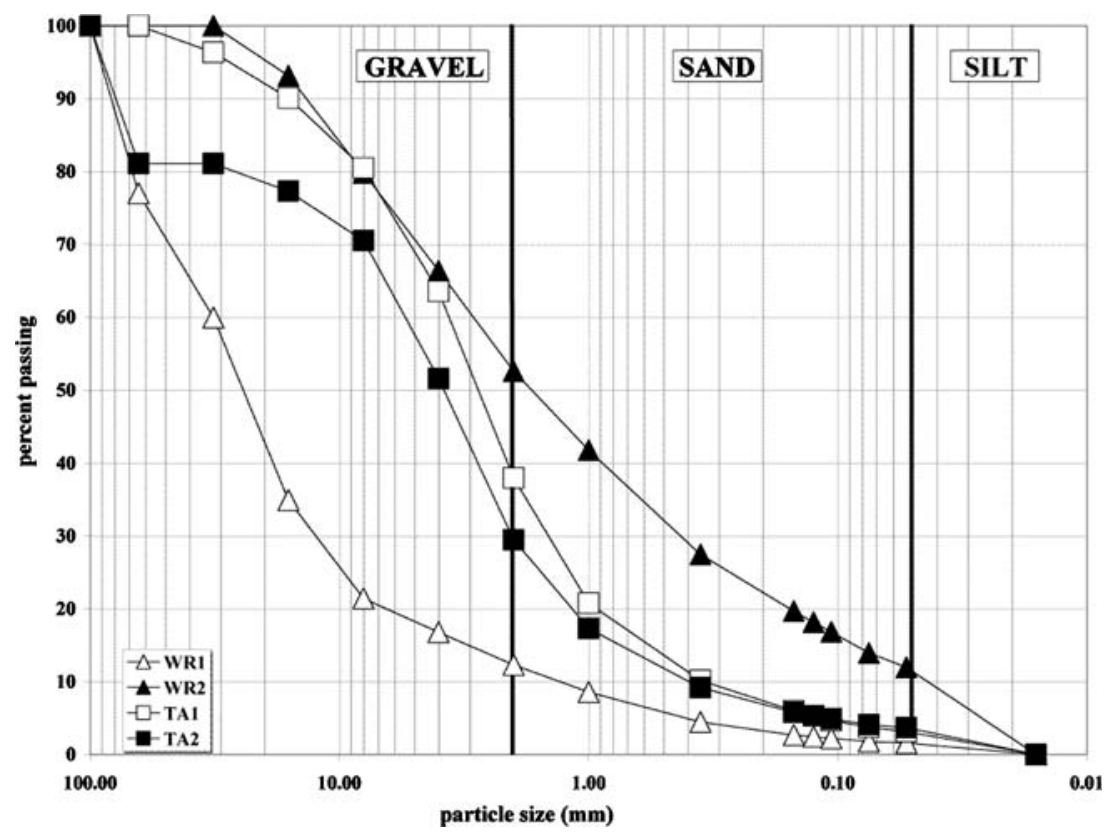


The TA, WR1, and WR2 dumps showed significant mineralogical variability (Table 1, Fig. 6) that reflected differences in both the primary waste material and in the style and degree of alteration.

The TA samples were dominated by secondary Fe-oxides and -oxyhydroxides (70-90\%; Table 1, Figs. 6, 7a) that occured as ochreous to reddish to brown cryptocrystalline aggregates completely replacing primary sulphide clasts. They sometimes pseudomorphically replaced gangue and host-rock mineral assemblages and even occurred as intergrain coatings that filled interstices and acted as cement between fragments. The main secondary mineral species recognised were, in order of decreasing abundances, goethite, lepidocrocite, and minor hematite. Brochantite $\left(\mathrm{Cu}_{4}(\mathrm{OH})_{6} \mathrm{SO}_{4}\right)$, Fe hydroxy-sulphates, and native copper commonly occured in voids formed by the dissolution of chalcopyrite. Aggregates of flake-shaped Fe-rich smectites were detected, in minor quantities, as intergrain phases or in the alteration rims of sulphide grains, together with Fe-oxyhydroxides.

Primary unaltered sulphides represented a minor to a trace component of the tailing material $(\leq 3-5 \%$; Table 1 , Fig. 6). Pyrite was, by far, the main sulphide mineral and occurred as millimetric $(0.2-1 \mathrm{~mm})$ idiomorphic cubic crystals rimmed by thin $(0.005-0.01 \mathrm{~mm})$ cryptocrystalline aggregates of Fe-oxyhydroxides (Fig. 7b). It also occurred as aggregates of allotriomorphic submillimetric (0.001$0.01 \mathrm{~mm}$ ) crystals often associated with minor chalcopyrite and sphalerite. In this case the sulphides were partially to almost completely replaced by Fe-oxyhydroxides in a pseudomorphic pattern. The Fe-oxyhydroxides also filled intergranular spaces creating a boxwork texture, similar to that described by Jeong and Lee (2003). Unaltered chalcopyrite and sphalerite were rare; all the analysed grains

Table 1 Mineralogy of the samples studied

\begin{tabular}{|c|c|c|c|c|c|c|}
\hline Sample & $\begin{array}{l}\text { Primary minerals (gangue } \\
\text { and host rocks) }\end{array}$ & $\%$ & $\begin{array}{l}\text { Primary minerals } \\
\text { (unaltered sulphides) }\end{array}$ & $\%$ & Secondary minerals & $\%$ \\
\hline A1a & $\begin{array}{l}\text { Srp (8), Pl (3), Mag (1), Chl (2), } \\
\text { Px (2), Qtz (1) }\end{array}$ & 17 & Py (4), Ccp (1), Sp (tr) & 5 & Gt (65), Lp (10), Fe-ox (3), Hem (tr), Br (tr), Cu (tr) & \\
\hline TA1b & $\begin{array}{l}\text { Srp (1)), Pl (1), Mag (tr), Chl (2), } \\
\quad \text { Px (1), Qtz (1) }\end{array}$ & 6 & Py (4), Ccp (1), Sp (tr) & 5 & Gt (75), Lp (10), Fe-ox (4), Hem (tr), Br (tr) & \\
\hline TA2a & $\begin{array}{l}\text { Srp (1), Pl (tr), Mag (tr), Chl (2), } \\
\text { Px (tr), Qtz (tr) }\end{array}$ & 3 & Py (4), Ccp (1), Sp (tr) & 5 & Gt (80), Lp (10), Fe-ox (2), Hem (tr), Br (tr) & 9 \\
\hline TA2b & $\begin{array}{l}\text { Srp (1), Pl (1), Mag (tr), Chl (tr), } \\
\quad \text { Px (1), Qtz (tr) }\end{array}$ & 3 & Py (2), Ccp (1), Sp (tr) & 3 & Gt (80), Lp (10), Fe-ox (4), Hem (tr) & \\
\hline WR1a & $\begin{array}{l}\text { Srp (3), Pl (3), Mag (1), Chl (2), } \\
\text { Px (2), Qtz (2) }\end{array}$ & 13 & $\begin{array}{l}\text { Py (6), Ccp (1), Sp (tr), } \\
\text { Cc (tr), Pn (tr) }\end{array}$ & 7 & $\begin{array}{l}\text { Gt (70), Hem (2), Fe-ox (8), Gp (tr), Epm (tr), } \\
\text { Mlt (tr), Bb (tr), Sdt (tr) }\end{array}$ & \\
\hline WR1b & $\begin{array}{l}\text { Srp (2), Pl (3), Mag (1), Chl (2), } \\
\text { Px (2), Qtz (1) }\end{array}$ & 11 & $\begin{array}{l}\text { Py (36), Ccp (7), Sp (2), } \\
\text { Cc (tr), Pn (tr) }\end{array}$ & 45 & $\begin{array}{l}\text { Gt (40), Hem (2), Fe-ox (2), Gp (tr), Epm (tr), } \\
\text { Mlt (tr), Bb (tr), Sdt (tr) }\end{array}$ & \\
\hline WR1c & $\begin{array}{l}\text { Srp (4), Pl (5), Mag (1), Chl (3), } \\
\text { Px (3), Qtz (1) }\end{array}$ & 17 & $\begin{array}{l}\text { Py (41), Ccp (7), Sp (2), } \\
\text { Cc (tr), Pn (tr) }\end{array}$ & 50 & $\begin{array}{l}\text { Gt (30), Hem (1), Fe-ox (2), Gp (tr), Epm (tr), } \\
\text { Mlt (tr), Bb (tr), Sdt (tr) }\end{array}$ & 3 \\
\hline WR1d & $\begin{array}{l}\text { Srp (2), Pl (3), Mag (tr), Chl (2), } \\
\text { Px (2), Qtz (1) }\end{array}$ & 10 & $\begin{array}{l}\text { Py (47), Ccp (8), Sp (3), } \\
\text { Cc (tr), Pn (tr) }\end{array}$ & 58 & $\begin{array}{l}\text { Gt (30), Fe-ox (2), Hem (tr), Gp (tr), Epm (tr), } \\
\text { Mlt (tr), Bb (tr), Sdt (tr) }\end{array}$ & 32 \\
\hline WR2a & $\begin{array}{l}\text { Srp (37), Pl (6), Mag (10), Chl (16), } \\
\quad \text { Px (3), Qtz (2) }\end{array}$ & 74 & Py (1), Ccp (tr), Sp (tr) & 1 & Gt (20), Fe-ox (3), Smc (2), Mal (tr), Gp (tr), Az (tr) & 2 \\
\hline WR2b & $\begin{array}{l}\text { Srp (42), Pl (7), Mag (9), Chl (23), } \\
\quad \text { Px (4), Qtz (3) }\end{array}$ & 88 & Py (1), Ccp & 1 & Gt (9), Fe-ox (1), Smc (1), Mal (tr), Gp (tr), Az (tr) & 1 \\
\hline WR2c & $\begin{array}{l}\text { Srp (45), Pl (5), Mag (11), Chl (18), } \\
\text { Px (2), Qtz (3) }\end{array}$ & 84 & Py (1), Ccp (tr), Sp (tr) & 1 & Gt (10), Fe-ox (3), Smc (2), Mal (tr), Gp (tr), Az (tr) & 15 \\
\hline WR2d & $\begin{array}{l}\text { Srp (43), Pl (4), Mag (12), Chl (19), } \\
\text { Px (2), Qtz (3) }\end{array}$ & 83 & Py (1), Ccp (tr), Sp (tr) & 1 & Gt (13), Fe-ox (1), Smc (2), Mal (tr), Gp (tr), Az (tr) & 16 \\
\hline WR2e & $\begin{array}{l}\text { Srp (42), Pl (5), Mag (14), Chl (20), } \\
\quad \text { Px (2), Qtz (4) }\end{array}$ & 87 & Py (1), Ccp (tr), Sp (tr) & 1 & Gt (10), Fe-ox (1), Smc (1), Mal (tr), Gp (tr), Az (tr) & 12 \\
\hline WR2f & $\begin{array}{l}\text { Srp (41), Pl (4), Mag (12), Chl (18), } \\
\text { Px (3), Qtz (3) }\end{array}$ & 81 & Py (1), Ccp & 1 & Gt (15), Fe-ox (2), Smc (1), Mal (tr), Gp (tr), Az (tr) & \\
\hline
\end{tabular}

The relative proportions of the recognised minerals are reported in parentheses

Minerals have been abbreviated according to Kretz (1983)

$\operatorname{Tr}$ trace amount, $A z$ azurite, $B b$ bieberite, $B r$ brochantite, $C c$ chalcocite, $C c p$ chalcopyrite, $C h l$ chlorite, $C u$ native copper, Epm epsomite, $F e-o x$ undetermined Fe-oxides and -oxyhydroxides, Gp gypsum, Gt goethite, Hem hematite, Lp lepidocrocite, Mag magnetite, Mal malachite, Mlt melanterite, $P n$ pentlandite, $P l$ plagioclase, $P x$ pyroxene, $P y$ pyrite, $Q t z$ quartz, $S d t$ siderotil, $S m c$ smectites, $S p$ sphalerite, $S r p$ serpentine group minerals 
Fig. 6 Modal abundance of the primary and secondary minerals within the tailing $(T A)$ and waste-rock dumps (WR1-2), black bar indicates primary ore minerals, dark grey bar indicates primary-gangue and host-rock minerals, light grey bar indicates secondary minerals
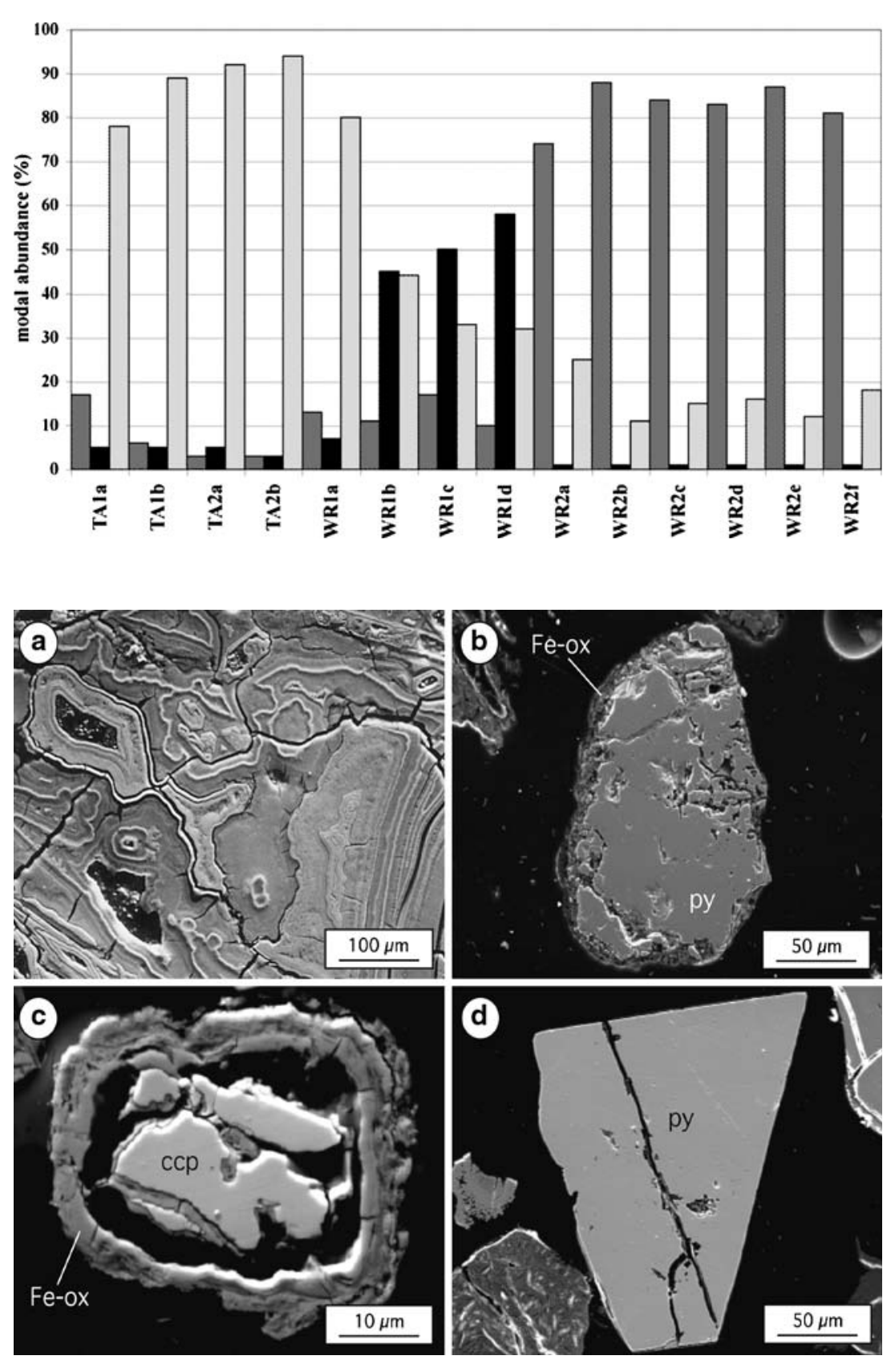

Fig. 7 Secondary electron SEM microphotographs of: a Fe-oxyhydroxides completely replacing primary minerals and filling voids with concentric layering; $\mathbf{b}$ a pyrite (py) grain partially replaced by $\mathrm{Fe}$ oxyhydroxides along the crystal edge and intracrystalline fractures; c typical alteration pattern of chalcopyrite ( $c c p)$ crystals with an unaltered core concentrically surrounded by a void space and a $\mathrm{Fe}$ -

oxyhydroxide ( $\mathrm{Fe}$-ox) outer rim; a completely unaltered pyrite crystal within the WR1d sample (note the complete absence of alteration also in the intragranular fractures and voids) were almost completely replaced by $\mathrm{Fe}$-oxyhydroxides with complex textural features growing around an unaltered submillimetric core. The fresh chalcopyrite grains were frequently completely surrounded by a void space (50-200 $\mu \mathrm{m}$ thick) (Fig. 7c). Some of the void rims contained relics of globular aggregates of $\mathrm{Fe}$ and/or $\mathrm{Cu}$ sulphates. The primary gangue and host rock minerals represented less than $20 \%$ of the total tailing material (Table 1, Fig. 6) and were mainly represented by mineral species characteristic of basalts (plagioclase, clinopyroxenes, chlorite, titanite, spinels, and apatite) and serpentinites (lizardite, chrysotile, magnetite, chromite, Ti-bearing spinels, chlorite, and plagioclase). This tailing dump was so weathered that even plagioclase grains were often partially replaced by secondary authigenic phases along the grain edges and/or twinning planes. Lizardite, and in particular chrysotile, were the best preserved minerals, whereas magnetite and spinels were mostly oxidised along grain boundaries and intergranular fractures.

The WR1 samples contained high quantities of primary sulphides and secondary minerals (Table 1, Fig. 6). The primary gangue and host-rock minerals were generally unaltered and represented less than $20 \%$ of the deposited material and were mainly represented by mineral species resulting from the comminution of basalts. The primary sulphides were dominated by pyrite, 
occurring as unaltered isolated millimetric idiomorphic crystals and as massive aggregates of micrometric allotriomorphic crystals. Chalcopyrite represented less than $10 \mathrm{wt} \%$ of the recognised sulphides and mainly occurred in association with pyrite in stockwork-vein assemblages or in massive irregular masses. Sphalerite was generally a minor component and occurred as interstitial allotriomorphic crystals within pyrite \pm chalcopyrite assemblages. The only other sulphides found during this study were very tiny amounts of chalcocite and pentlandite.

The secondary minerals were mainly represented by $\mathrm{Fe}$ oxyhydroxides and -oxides (goethite and minor hematite and lepidocrocite) that had replaced primary sulphides, filling voids and fractures, and coating intergranular and intragranular surfaces. Sulphates (gypsum- $\mathrm{CaSO}_{4} \cdot 2 \mathrm{H}_{2} \mathrm{O}$; epsomite- $\mathrm{MgSO}_{4} \cdot 7 \mathrm{H}_{2} \mathrm{O} ; \quad$ melanterite $-\mathrm{FeSO}_{4} \cdot 7 \mathrm{H}_{2} \mathrm{O}$; bieberite- $\mathrm{CoSO}_{4} \cdot 7 \mathrm{H} 2 \mathrm{O}$; siderotil- $\mathrm{FeSO}_{4} \cdot 5 \mathrm{H}_{2} \mathrm{O}$ ) commonly occurred as ephemeral blooms on the surface of the waste deposit or within intergranular voids during dry seasons.

The primary sulphide:secondary mineral ratio, as well as the style and intensity of the sulphide alteration, significantly increased with depth (i.e. from WR1a to WR1d samples; Table 1, Fig. 6). In fact, in the WR1a sample, fresh sulphide crystals were mainly present as relics within oxyhydroxide masses or in the core of pseudomorphic replacements. With increasing depth, i.e. from the WR1b to the WR1d samples, the sulphide crystals were only partially altered, being replaced only along the edges and within intragranular fractures. Completely unaltered grains commonly occurred only in the WR1c and WR1d samples (Fig. 7d), where the best preserved sulphides were idiomorphic pyrite crystals.
The WR2 samples were dominated by primary gangue and host-rock minerals, mainly represented by serpentinite mineral assemblages (lizardite, chrysotile, magnetite, chromite, Ti-bearing spinels, chlorite, minor clinopyroxene, plagioclase, and calcite). It is important to note that magnetite and Cr-bearing spinels represented about 10 $15 \%$ of the identified minerals occurring as strongly mineralised clasts, as isolate idiomorphic crystals, and/or as trails of allotriomorphic grains within mesh and ribbon textures.

Sulphide minerals were a very minor component $(\leq 1 \mathrm{wt} \%)$ and they were scattered throughout the sampled sections as fresh or weakly-altered idiomorphic and subidiomorphic grains, mainly represented by pyrite. When present, alteration developed along the edges of the crystals, producing submillimetric concentric rims of Fe-oxyhydroxides.

Secondary minerals were more abundant in the first $25 \mathrm{~cm}$ (up to $25 \mathrm{wt} \%$ in sample WR2a) and sharply decreased in the deeper samples (Table 1, Fig. 6). Also in this part of the waste-rock dump the main secondary mineral species were the Fe-oxyhydroxides and -oxides, but, even if in very subordinate amounts, gypsum and $\mathrm{Cu}$-carbonates [malachite- $\mathrm{Cu}_{2}\left(\mathrm{CO}_{3}\right)_{2}(\mathrm{OH})_{2}$ and azurite- $\left.\mathrm{Cu}_{3}\left(\mathrm{CO}_{3}\right)_{2}(\mathrm{OH})_{2}\right]$ were diffuse in all samples. The other peculiar feature of the WR2 samples was the common occurrence of clay minerals, mainly represented by Fe-bearing smectites.

\section{Mineral chemistry}

Representative SEM-EDS analyses of the primary sulphides (from the WR1 site) and secondary Fe-oxyhydroxides (from the TA and WR1 sites) are reported in Table 2.

Table 2 Representative analyses of the primary sulphides and secondary Fe-oxyhydroxides

\begin{tabular}{|c|c|c|c|c|c|c|c|c|c|c|c|c|c|c|}
\hline $\begin{array}{l}\text { Site } \\
\text { (wt } \%)\end{array}$ & $\begin{array}{l}\text { WR1 } \\
\text { (Py) }\end{array}$ & $\begin{array}{l}\text { WR1 } \\
\text { (Py) }\end{array}$ & $\begin{array}{l}\text { WR1 } \\
\text { (Py) }\end{array}$ & $\begin{array}{l}\text { WR1 } \\
\text { (Ccp) }\end{array}$ & $\begin{array}{l}\text { WR1 } \\
\text { (Ccp) }\end{array}$ & $\begin{array}{l}\text { WR1 } \\
\text { (Ccp) }\end{array}$ & $\begin{array}{l}\text { WR1 } \\
(\mathrm{Sp})\end{array}$ & $\begin{array}{l}\text { WR1 } \\
\text { (Sp) }\end{array}$ & $\begin{array}{l}\text { WR1 } \\
(\mathrm{Cc})\end{array}$ & $\begin{array}{l}\text { WR1 } \\
(\mathrm{Pn})\end{array}$ & $\begin{array}{l}\text { TA } \\
(\mathrm{Fe}-\mathrm{ox})\end{array}$ & $\begin{array}{l}\text { TA } \\
\text { (Fe-ox) }\end{array}$ & $\begin{array}{l}\text { WR1 } \\
\text { (Fe-ox) }\end{array}$ & $\begin{array}{l}\text { WR1 } \\
\text { (Fe-ox) }\end{array}$ \\
\hline $\mathrm{Si}$ & & & & & & & & & & & 0.92 & 0.68 & 1.38 & 1.07 \\
\hline $\mathrm{Al}$ & & & & & & & & & & & 0.90 & 2.32 & 0.55 & 0.55 \\
\hline $\mathrm{Ti}$ & & & & & & & & & & & 0.19 & 0.41 & 0.29 & 0.53 \\
\hline $\mathrm{Mn}$ & & & & & & & & & & & 0.05 & 0.15 & 0.9 & 0.23 \\
\hline $\mathrm{Fe}$ & 45.79 & 45.08 & 44.84 & 30.37 & 30.60 & 30.29 & 3.36 & 3.06 & 0.11 & 23.97 & 59.06 & 53.5 & 52.06 & 52.06 \\
\hline $\mathrm{Cu}$ & 1.87 & 0.50 & 0.73 & 34.83 & 34.92 & 34.52 & 0.76 & 0.04 & 78.81 & 0.02 & 0.59 & 0.26 & 0.7 & 0.7 \\
\hline $\mathrm{Ni}$ & 0.35 & 1.69 & 1.80 & 0.05 & 0.03 & 0.02 & 2.19 & 1.39 & 0.21 & 41.60 & 1.21 & 2.89 & 4.12 & 4.12 \\
\hline Co & 0.09 & 0.30 & 0.66 & 0.11 & 0.15 & 0.23 & 0.05 & 0.01 & 0.10 & 1.04 & 0.80 & 1.50 & 2.9 & 2.9 \\
\hline $\mathrm{Zn}$ & 0.71 & 0.63 & 0.89 & 0.23 & 0.15 & 0.26 & 60.52 & 62.53 & 0.01 & 0.01 & 0.30 & 0.90 & 0.60 & 0.60 \\
\hline $\mathrm{Cr}$ & & & & & & & & & & & 0.09 & 0.04 & 0.15 & 0.1 \\
\hline$S$ & 51.51 & 52.11 & 51.24 & 34.60 & 34.54 & 34.84 & 33.25 & 33.15 & 20.67 & 33.08 & 1.25 & 3.24 & 1.72 & 2.72 \\
\hline Total & 100.32 & 100.31 & 100.16 & 100.19 & 100.39 & 100.16 & 100.13 & 100.18 & 99.91 & 99.72 & 65.36 & 65.89 & 65.37 & 65.58 \\
\hline
\end{tabular}

Abbreviations as in Table 1 
Pyrite $(\mathrm{Cu} \leq 2.5 \mathrm{wt} \%)$ was the only primary mineral that contained significant amounts of copper other than chalcopyrite. Moreover, together with sphalerite, pyrite, and chalcopyrite are the main $\mathrm{Zn}$-bearing minerals (up to $0.9 \mathrm{Zn}$ wt\% for pyrite, and up to $0.4 \mathrm{Zn} \mathrm{wt} \%$ for chalcopyrite). Significant amounts of nickel were detected in pyrite (up to $3 \mathrm{wt} \%$ ) and sphalerite (up to $2.5 \mathrm{wt} \%$ ) as well as in a few examples of pentlandite. Finally, although the EDS analyses did not indicate detectable concentrations of other elements, significant amounts of As, Ag, Mo, and Se are known to occur in massive mineralisations (Marescotti and Carbone 2003) and in the pyrite crystals (Carbone et al. 2005a).

The secondary Fe-oxides and -oxyhydroxides were invariably enriched with $\mathrm{Si}(0.5-2 \mathrm{wt} \%), \mathrm{Al}(0.3-2.5 \mathrm{wt} \%)$, $\mathrm{S}(0.2-3.5 \mathrm{wt} \%), \mathrm{Cu}(0.01-0.1 \mathrm{wt} \%)$, Ti $(0.05-0.5 \mathrm{wt} \%)$, $\mathrm{Ni}(0.1-1.1 \mathrm{wt} \%), \mathrm{Co}(\leq 0.5 \mathrm{wt} \%), \mathrm{Cr}(\leq 0.1 \mathrm{wt} \%)$, and $\mathrm{Mn}(\leq 0.1 \mathrm{wt} \%)$. The presence of these enrichments could be related to isomorphous substitution (such as $\mathrm{Ni}$ and $\mathrm{Co}$ in goethite; Cornell and Schwertmann 1996) or to other incorporation mechanisms, such as co-precipitation and/or sorption. Moreover, the presence of residual cryptocrystalline primary minerals cannot be excluded.

\section{Geochemical results}

\section{Bulk chemistry}

The bulk chemistry analyses confirmed that the three sites studied were very different in terms of their major and trace element concentrations (Fig. 8a, b).

The TA samples had the highest Fe and other transitionand heavy-metal content and a lower total $\mathrm{S}$ content than all the WR1 samples. If normalised to the mean bulk chemistry of the massive Libiola mineralisations, they were invariably depleted of sulphur and enriched in most transition and heavy metals (Fig. 9).

The WR1 samples were generally characterised by a high metal content and the highest total S concentration, confirming that most of the metals were still mainly present within unaltered sulphides. This was also demonstrated by the normalisation of the WR1 samples to the mean bulk chemistry of the massive mineralisation (Fig. 9). It is important to note that the sulphur and metals are positively correlated and their amounts progressively increase from the surface (WR1a) towards the deeper samples (WR1b-d; Table 3, Fig. 8a, b).

The WR2 samples were characterised by high $\mathrm{Fe}, \mathrm{Mg}$, $\mathrm{Ni}$, and $\mathrm{Cr}$ concentrations and by relatively low $\mathrm{Cu}$ and total $\mathrm{S}$ contents; these compositions were consistent with an average elemental concentration of a serpentinite-rich material partially enriched with sulphur, iron, and copper due to the presence of relatively small amounts of sulphide mineralisations.
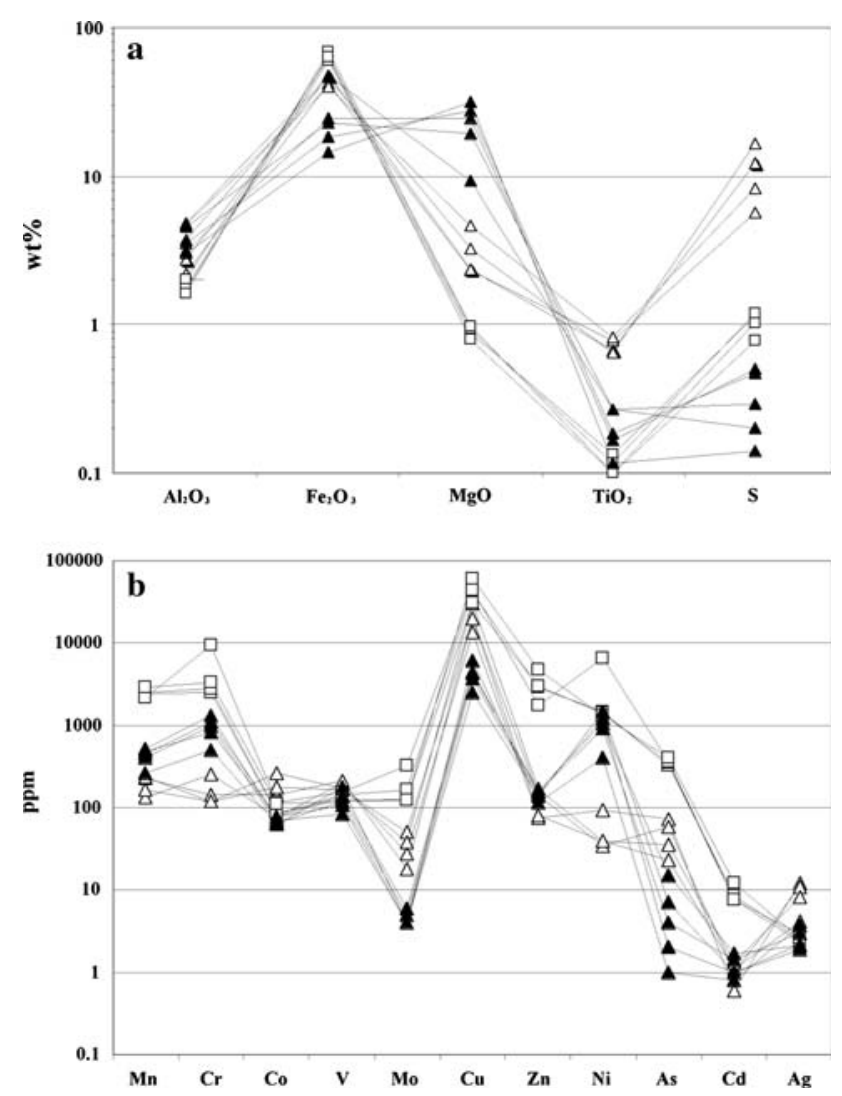

Fig. 8 Bulk chemistry of the TA and WR samples: a selected major elements; b selected minor and trace elements. Open triangles indicate WR1, open squares indicate TA, filled triangles indicate WR2

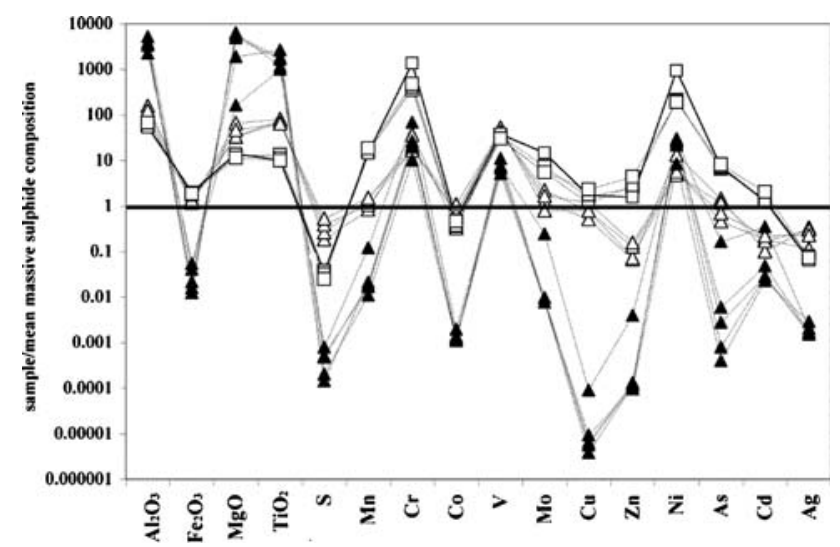

Fig. 9 Composition of the WR and TA samples normalised to the mean composition of the massive sulphide mineralisations of Libiola (data adapted from Marescotti and Carbone 2003). Symbols as in Fig. 8

AMD evaluation

The AMD evaluation results are summarised in Table 3. All the NAPP values of the WR2 samples were negative 
Table 3 AMD evaluation results

\begin{tabular}{|c|c|c|c|c|c|c|c|c|c|}
\hline Sample & $\begin{array}{l}\text { Total S } \\
\text { (wt } \%)\end{array}$ & $\begin{array}{l}\text { S sulphate } \\
\text { (wt\%) }\end{array}$ & $\begin{array}{l}\text { S sulphide } \\
\text { (wt } \%)\end{array}$ & $\begin{array}{l}\text { S sulphate/ } \\
\text { S sulphide }\end{array}$ & $\begin{array}{l}\text { Total S MPA } \\
\left(\mathrm{H}_{2} \mathrm{SO}_{4} \mathrm{~kg} / \mathrm{t}\right)\end{array}$ & $\begin{array}{l}\text { Sulphide MPA } \\
\left(\mathrm{H}_{2} \mathrm{SO}_{4} \mathrm{~kg} / \mathrm{t}\right)\end{array}$ & $\begin{array}{l}\text { ANC } \\
\left(\mathrm{H}_{2} \mathrm{SO}_{4}\right. \\
\mathrm{kg} / \mathrm{t})\end{array}$ & $\begin{array}{l}\text { Total S NAPP } \\
\left(\mathrm{H}_{2} \mathrm{SO}_{4} \mathrm{~kg} / \mathrm{t}\right)\end{array}$ & $\begin{array}{l}\text { Sulphide NAPP } \\
\left(\mathrm{H}_{2} \mathrm{SO}_{4} \mathrm{~kg} / \mathrm{t}\right)\end{array}$ \\
\hline WR1a & 5.71 & 0.85 & 4.86 & 0.17 & 174.73 & 148.72 & 0.00 & 174.70 & 148.72 \\
\hline WR1b & 8.20 & 1.72 & 6.48 & 0.27 & 250.92 & 198.29 & 41.80 & 209.10 & 156.49 \\
\hline WR1c & 12.20 & 2.78 & 9.42 & 0.30 & 373.32 & 288.25 & 0.00 & 373.30 & 288.25 \\
\hline WR1d & 16.52 & 2.43 & 14.09 & 0.17 & 505.51 & 431.15 & 37.00 & 468.50 & 394.15 \\
\hline $\mathrm{T} 1 \mathrm{a}$ & 1.16 & 0.25 & 0.91 & 0.27 & 35.50 & 27.85 & 0.00 & 35.50 & 27.85 \\
\hline $\mathrm{T} 1 \mathrm{~b}$ & 1.20 & 0.27 & 0.93 & 0.29 & 36.72 & 28.46 & 16.03 & 20.70 & 12.43 \\
\hline $\mathrm{T} 2 \mathrm{a}$ & 1.03 & 0.41 & 0.62 & 0.66 & 31.52 & 18.97 & 0.00 & 31.50 & 18.97 \\
\hline $\mathrm{T} 2 \mathrm{~b}$ & 0.78 & 0.25 & 0.53 & 0.47 & 23.87 & 16.22 & 6.79 & 17.10 & 9.43 \\
\hline WR2a & 0.50 & - & 0.50 & - & 15.30 & - & 83.92 & -68.60 & - \\
\hline WR2b & 0.14 & - & 0.14 & - & 4.28 & - & 51.62 & -47.30 & - \\
\hline WR2c & 0.20 & - & 0.20 & - & 6.12 & - & 156.52 & -150.40 & - \\
\hline WR2d & 0.47 & - & 0.47 & - & 14.23 & - & 41.99 & -27.75 & - \\
\hline WR2f & 0.29 & - & 0.29 & - & 8.87 & - & 21.32 & -12.40 & - \\
\hline
\end{tabular}

Total $\mathrm{S}$ and sulphate $\mathrm{S}$ were analysed, whereas sulphide $\mathrm{S}$ was calculated as the difference between total $\mathrm{S}$ and sulphate $\mathrm{S}$. MPA was calculated both for total $\mathrm{S}$ and sulphide $\mathrm{S}$ using the equation: MPA $=\mathrm{S} \times 30.6$. ANC was measured with titration after "fizz test". When a negative value of ANC is obtained, it is reported as 0.00 , which indicates the sample incapacity of neutralization. NAPP was calculated both for total S and sulphide $\mathrm{S}$

and no AMD process could occur independently of the sulphate/sulphide ratio. On the other hand, all the NAPP values of the WR1 and TA samples were positive and to assess the possibility of AMD processes the sulphate content was determined. The total $\mathrm{S}$ and sulphide $\mathrm{S}$ were then plotted against the NAPP, following Soregaroli and Lawrence (1997; Fig. 10).

The WR2 samples fell in the non-acid forming fields (III and IV). The WR1 samples fell in field II where AMD occurs and, due to the high $\mathrm{S}$ content, it can last for a long time. The TA samples also fell in field II, but very close to its lower edge highlighting the possibility of producing very limited and non-persisting AMD. Taking the sulphide:sulphate ratio into account, the position of the WR1 and TA samples did not change fields (Fig. 10).

\section{Discussion}

AMD processes and their evolution

The AMD processes within the tailing and waste-rock dumps studied were significantly different from site to site, and even within a vertical metric section (e.g. the WR1
Fig. 10 a Total S NAPP values vs. total S contents; b Sulphide NAPP values vs. sulphide $S$ contents. Field I: AMD possible but not persisting in time due to low S content; Field II: AMD possible and persisting in time due to high S content; Fields III and $I V$ : AMD impossible. 0.3 $\mathrm{wt} \% \mathrm{~S}$ as limit above which AMD is persisting, from Soregaroli and Lawrence (1997). Symbols as in Fig. 8
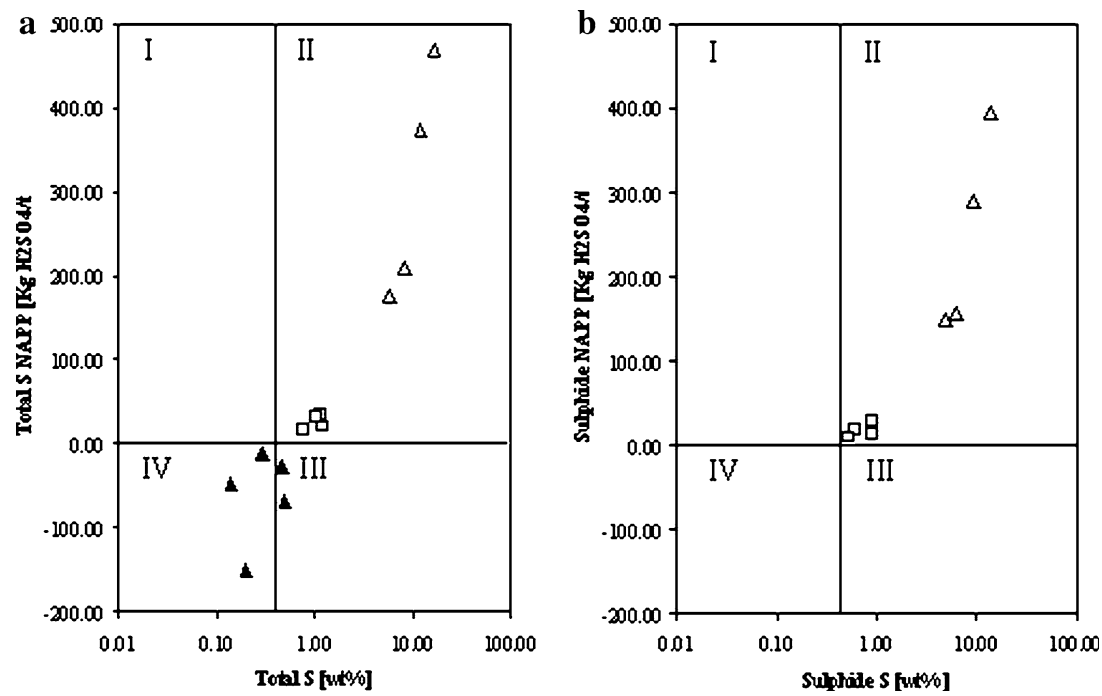
section). If the WR2 site is excluded due to its insufficient AMD potential, the differences observed between the other sites studied allowed us to recognise different stages of the AMD evolution, following the paragenetic scheme described in Jambor (2003).

The TA dump represents a "late stage" of the AMD evolution; it crops out as a strongly-cemented body capped by a very coherent hardpan that acts as a barrier able to prevent significant water and oxygen circulation. Few traces of potentially reactive sulphides were still present, and the waste material was mostly composed of secondary minerals, mainly represented by evolved and poorly-soluble goethite \pm lepidocrocite \pm hematite assemblages. The permanent non-acidic environment and the low permeability prevented significant leaching of the metals adsorbed by and/or incorporated in the newly-formed authigenic phases (Fig. 9), which therefore represented an efficient sink for potentially toxic elements leached from the sulphides, gangue, and host-rock minerals. This advanced state of AMD evolution can be explained by the original high reactivity of the tailing material (i.e. pyriterich sediments derived from both mechanical grinding and handpicking operations) and by their anomalous open-air setting. In particular, this last feature determined weathering processes that were substantially different from those that normally occur within the more common tailing locations (i.e. within subaqueous impoundments) characterised by thick saturated zones that can efficiently minimise oxidation (Jambor and Blowes 1994).

At the WR1 site at least two different stages of the AMD evolution could be distinguished as a function of their depth within the dump pile.

The superficial part $(0-25 \mathrm{~cm})$ corresponded to a "transition from an early- to a maturing-stage" (stage 2 early alteration; Jambor 2003) where most of the sulphides were at least partially altered. The chalcopyrite, sphalerite and microcrystalline pyrite aggregates, in particular, were pseudomorphically replaced by Fe-oxyhydroxides starting at the edge of the crystals and along intragranular fractures or intergranular grain boundaries. The macrocrystalline and idiomorphic pyrite crystals were the best preserved sulphides and their ongoing alteration was marked only by the presence of a narrow rim of $\mathrm{Fe}$-oxyhydroxide replacement. This part of the WR1 section had not yet reached a mature stage due to two main factors: (a) the slope of the WR dump and the consequent high energy of the surface runoff that periodically removed the superficial crusts, thus renewing the reacting materials; (b) the wet-dry cycles occurring at the microscale in this superficial and unsaturated layer determined desiccation of the oxyhydroxides that rimmed the unaltered sulphide cores. This process readily caused their cracking and removal (Pratt et al. 1994) thereby exposing fresh sulphide surfaces and trig- gering new alteration processes. The presence of a surface layer depleted of sulphur and metals demonstrated that most of the ions released during the sulphide weathering were only temporarily stored within poorly-crystalline $\mathrm{Fe}$ oxyhydroxides and/or superficial water-soluble sulphate efflorescences and that they were then removed from the dump during wet seasons.

The deeper part of the WR1 section $(25-100 \mathrm{~cm})$, corresponding to an "early stage" of the AMD evolution (stage 1 early alteration; Jambor 2003), was characterised by slightly altered or unaltered sulphides (in particular pyrite). The secondary minerals mainly occurred within interstices, thus coating clast surfaces and filling voids and fractures. These occurrences suggest that the secondary minerals mainly precipitated from the solutions moving downwards from the superficial layer. The initial alteration of the sulphides was marked by thin Fe-oxyhydroxide replacement along the crystal edges. The presence of this early paragenetic stage indicated that the waters infiltrating from the upper layer were modified solutions that were oversaturated with respect to most transition and heavy metals.

Other than exposure to weathering agents, the following seem to be the main factors responsible for the present evolution of the AMD processes: (1) the grain size of the dumped material, (2) the content in sulphides and their mode of occurrence.

1) The grain size of the deposited materials seemed to be an efficient factor in controlling the speed of the AMD processes. Despite a decrease in porosity with decreasing particle size, thus limiting or inhibiting the water-rock interaction, the clayey and silty fractions represented a minor component of the material studied, which consisted of gravel- and sand-dominated sediments. Consequently, the other factor directly correlated to the decrease in the grain size (i.e. the increase in the surface:volume ratio) strongly favoured reactivity and rapid interaction with the circulating waters. For this reason, the milled sulphide mineralisations of the TA deposit were also the most AMDactive sites, rapidly overcame the reactive stage and now represent an almost inert body, mostly composed of stable secondary mineral assemblages.

2) The sulphide content of the tailing and waste-rock dumps is obviously one of the main factors in triggering and controlling the evolution of the AMD processes. Nevertheless the mode of occurrence of the sulphide mineralisations (i.e. the size of the mineralised fragments and their textural features) can significantly influence the overall process. The TA site originally had the highest sulphide (mainly pyrite) content and the mineralised clasts were present as 
fragments of nearly pure sulphide assemblages or, subordinately, as single sulphide grains. This represented the best condition for triggering oxidation processes that rapidly consumed the sulphides. On the contrary, the WR1 samples contained unsorted and untreated waste material; the sulphide-bearing fragments occurred either as massive and partially mineralised clasts included in a silicate matrix. The first type was generally more altered and was partially to almost completely replaced by Fe-oxyhydroxide and oxide authigenic phases that had developed from the outer surfaces towards the cores. The second type was mostly represented by fragments of stockwork mineralisations that contained sulphides within their vein networks. Alteration was most effective along the vein walls and sometimes extended to the adjoining rock as reddish to ochreous oxidation halos. In both cases the AMD processes were slower than those occurring in the tailings due to the lower surface:volume ratio and the efficient shield effects provided by the authigenic secondary minerals and/or by the surrounding silicate matrix. Finally, the low sulphide mineralisation quantity prevented significant AMD processes within the WR2 portion of the dump.

The sulphide types and their relative proportions were almost the same in both the TA and WR samples and thus they did not represent a discriminant factor in controlling the different evolutions of the AMD processes. Nevertheless, the observed relative reactivity of the sulphide minerals in both the tailings and waste rocks was consistent with those reported in Jambor and Blowes (1994) and can be established as, in decreasing order of resistance, sphalerite $>$ chalcopyrite $>$ pyrite .

\section{Environmental concern}

This study highlighted that the waste rock dump (WR) is still capable of producing long-term AMD in specific sites characterised by significant enrichments of sulphide (pyrite-rich) mineralisations. Since the WR dump was constructed in several stages over a period of about 100 years with uncontrolled mixing of low-grade mineralisations and a variety of host-rock types, several different active AMD sites (such as WR1) may be vertically and laterally scattered throughout the entire deposit.

Besides the acidification of the surface and infiltrating waters, the other major environmental concern is represented by the release of a set of potentially toxic elements originally contained not only within the sulphides but also within the gangue and host-rock minerals (such as $\mathrm{Cr}$ and Ti). This hazard has been revealed not only by the published water analyses (Dinelli et al. 1999, 2001; Dinelli and
Tateo 2002; Marini et al. 2003; Accornero et al. 2005), but also by the bulk-chemistry and mineralogical analyses performed on the tailing and waste-rock material.

The contaminant concentrations in the TA and WR1 samples notably exceed the Italian legal limits for $\mathrm{Cu}, \mathrm{Ni}$, Co, and As (Fig. 11) in residential and industrial sites (Ministerial Decree 471/99; Legislative Decree 152/06). Moreover, TA samples also significantly exceed legal limits for $\mathrm{Cr}, \mathrm{Zn}, \mathrm{Cd}$, and $\mathrm{Sb}$ (Fig. 11).

It is important to determine where these metals can still be found. If they are present in the primary phases (sulphides, gangue, and host-rock minerals) they represent a potential hazard when affected by AMD processes. If they are incorporated in the secondary authigenic phases, it is important to evaluate the ability of these minerals to stably store these elements.

The mineralogical results and the positive correlation between the heavy metals and the NAPP in the WR1 samples (Fig. 12) confirm that the heavy metals are mostly present within sulphides and that they can be released

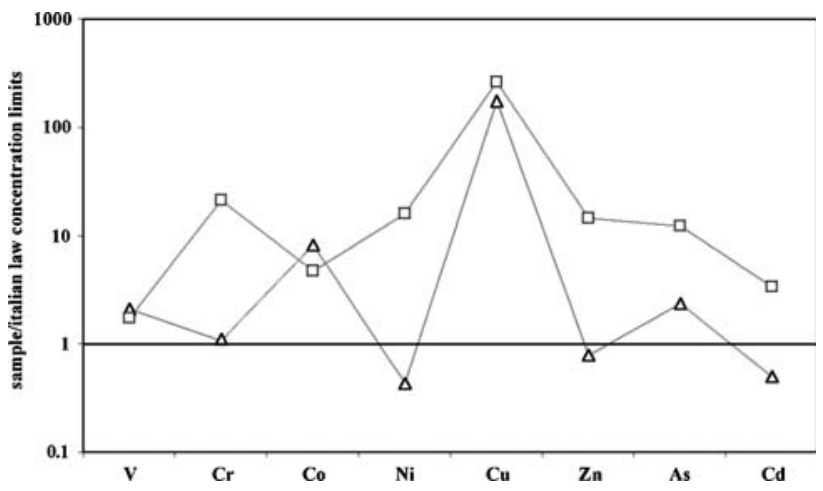

Fig. 11 Composition of TA and WR1 samples (selected hazardous minor and trace elements) normalised to Italian law concentration limits for residential and industrial sites (Ministerial Decree 471/99 and Legislative Decree 152/06). Symbols as in Fig. 8

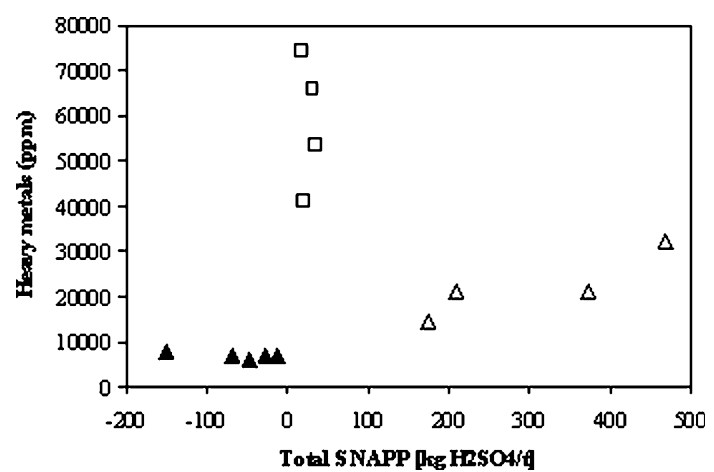

Fig. 12 Heavy metal content vs. total S NAPP values. Symbols as in Fig. 8 
during weathering of the latter. The lowest heavy-metal content and NAPP values were associated to sample WR1a, which was relatively poor in sulphides and rich in alteration minerals (Fig. 6). On the contrary, the high heavy-metal content and the lack of NAPP correlations of the TA samples suggest that the heavy metals are not associated with the sulphides but with the secondary minerals. This contrasting behaviour can be explained by the different evolutive stages of the AMD processes at the two sites. In fact, the AMD process is very active at the WR1 site and both primary sulphides and secondary minerals are still reacting and evolving. As revealed by a detailed mineralogical study on weathered crusts from the same waste-rock dump (Carbone et al. 2005b) and in a number of works on natural and synthetic Fe-oxides and -oxyhydroxides precipitated from acid solutions (Cornell and Schwertmann 1996 and references therein; Schwertmann et al. 1999; Banfield et al. 2000), such phases continuously undergo transformation processes from low-crystallinity/ amorphous phases towards more stable species such as hematite and goethite. During this evolution most of the metal cations sorbed by the pristine minerals are easily desorbed and returned in the reacting solutions. At the TA site, most of the secondary mineral assemblages (goethite \pm lepidocrocite \pm hematite) have already reached a stable state and represent an effective and stable sink for most of the metal ions released during sulphide alteration. This is consistent with the preliminary data on Fe-oxide and -oxyhydroxides crusts from the Libiola mine obtained from $\mu$-diffraction and $\mu$-fluorescence analyses (Carbone et al. 2005a), which show the high capacity of goethite- and hematite-rich assemblages to concentrate transition and heavy metals through adsorption, coprecipitation, and isomorphic mechanisms.

Finally, the low heavy-metal content and the negative NAPP values of the WR2 samples reflect the nature of the dumped material (i.e. poorly mineralised serpentinitic- and basaltic-bearing waste rocks).

It is important to state that most of the rock-forming minerals (silicates, magnetite, chromite, and other $\mathrm{Cr}$ - and Ti-rich spinels) of the Libiola waste-rock dumps that were once exposed to acid water circulation show significant degrees of alteration. Nevertheless, considering the mineral species involved, none of these have a fast enough reaction rate to efficiently counter the acidification induced by sulphide weathering (Jambor 2003 and references therein). On the other hand, they represent the main source of metals other than those contained within the sulphides. In fact, other than $\mathrm{Si}, \mathrm{Al}$, and $\mathrm{Mg}$, these minerals can also release (Dinelli and Tateo 2002) important quantities of $\mathrm{Cr}$, Mn, and $\mathrm{Ti}$ (magnetite, chromite, and other spinels), $\mathrm{V}$ (pyroxene), $\mathrm{Ni}$ (olivine and pyroxene), and $\mathrm{Rb}$ (plagioclase) into circulating solutions.
On the basis of our results it is evident that any effort to characterise the AMD processes and plan remediation at these hazardous waste sites must be made taking into account that in such a heterogeneous and complex system a simplified geochemical model does not unequivocally predict the effective AMD potential. The integration of mineralogical and geochemical studies of the solid phases is necessary to understand the potential reagents and the actual products of the reactions, the distribution of active or potentially activatable AMD sites, the evolutive stage reached at the different locations, and, finally, to evaluate the potential lifespan of the overall process.

Acknowledgements The Italian MIUR-Ministero dell'Istruzione, dell'Università e della Ricerca (PRIN-COFIN2003: “Crystal chemistry of ore minerals and their alteration products from polimetallic ore deposits in ligurian ophiolites" and PRIN-COFIN2006: "The role of mineral phases in the mobilisation and storage of contaminant elements within mining sites of eastern Liguria"') is acknowledged for financial support.

\section{References}

Abbate E, Bortolotti V, Galbiati B, Principi G (1980) Carta geologica delle ofioliti del bargonasco e dell'Alta Val Graveglia. S.E.L.C.A. Firenze

Accornero M, Marini L, Ottonello G, Vetuschi Zuccolini M (2005) The fate of major constituents and chromium and other trace elements when acid waters from the derelict Libiola mine (Italy) are mixed with stream waters. Appl Geochem 20:1368-1390

Banfield JF, Welch SA, Zhang H, Ebert TT, Penn RL (2000) Aggregation-based crystal growth and microstructural development in natural iron oxyhydroxide biomineralization products. Science 289:751-754

Carbone C, Marescotti P, Martinelli M, Lucchetti G (2005a) Characterisation by means of $\mu$-diffraction and $\mu$-fluorescence analyses of $\mathrm{Fe}$-oxyhydroxides heterogeneous aggregates formed by supergenic alteration of natural $\mathrm{Fe}-\mathrm{Cu}$-sulfides. ESRF-Internal Report-ID18F Experiment CH2095

Carbone C, Di Benedetto F, Marescotti P, Martinelli A, Sangregorio C, Cipriani C, Lucchetti G, Romanelli M (2005b) Genetic evolution of nanocrystalline $\mathrm{Fe}$ oxide and oxyhydroxide assemblages from the Libiola mine (eastern Liguria, Italy): structural and microstructural investigations. Eur J Miner 17:785-795

Cornell RM, Schwertmann U (1996) The iron oxides. structure, properties, reactions, occurrence and uses. VHC, Weinheim, $p$ 573

Decreto Legislativo n. 152 del 3 aprile (2006) (Legislative Decree 152/06) Norme in materia ambientale. Supplemento Ordinario no. 96 della Gazzetta Ufficiale

Decreto Ministeriale n. 471 del 25 ottobre (1999) (Ministerial Decree 471/99) Regolamento recante criteri, procedure e modalita' per la messa in sicurezza, la bonifica e il ripristino ambientale dei siti inquinati, ai sensi dell'articolo 17 del decreto legislativo 5 febbraio 1997, n. 22 , e successive modificazioni e integrazioni. Supplemento Ordinario 218/L alla Gazzetta Ufficiale n. 293 del 15 dicembre 1999

Dinelli E, Tateo F (2002) Different types of fine-grained sediments associated with acid mine drainage in the Libiola $\mathrm{Fe}-\mathrm{Cu}$ mine area (Ligurian Apennines, Italy). Appl Geochem 17:10811092 
Dinelli E, Cortecci G, Lucchini F, Fabbri M (1999) REE mobility associated to acid mine drainage: investigation in the Libiola area, northern Italy. Proceeding of geochemistry of earth's surface, 16-20 August 1999, Reykjavík, Iceland, pp 173-176

Dinelli E, Lucchini F, Fabbri M, Cortecci G (2001) Metal distribution and environmental problems related to sulphide oxidation in the Libiola copper mine area (Ligurian Apennines, Italy). J Geochem Explor 74:141-152

Ferrario A, Garuti G (1980) Copper deposits in the basal breccias and volcano-sedimentary sequences of the Eastern Ligurian ophiolites (Italy). Miner Dep 15:291-303

Garuti G, Zaccarini F (2005) Minerals of Au, Ag, and U in volcanicrock-associated massive sulphide deposits of the northern Apennine ophiolite, Italy. Can Mineral 43:935-950

Iwri, Egi (Ian Wark Research Institute, Environmental Geochemistry International) (2002) ARD test handbook. AMIRA P387A project: prediction and kinetic control of acid mine drainage. AMIRA International, Melbourne

Jambor JL (2003) Mine-waste mineralogy and mineralogical perspectives of acid-base accounting. In: Jambor JL, Blowes DW, Ritchie AIM (eds) Environmental aspects of mine wastes. Mineralogical Association of Canada Short Course Series 31, pp $17-146$

Jambor JL, Owens DR (1993) Mineralogy of tailings impoundment at the former $\mathrm{Cu}-\mathrm{Ni}$ deposit of Nickel Rim Mines Ltd. eastern edge of the Sudbury structure, Ontario. CANMET Div Rep. MSL 934(CF), Dept. Energy Mines Resources, Canada

Jambor JL, Blowes DW (1994) Short-course handbook on environmental geochemistry of sulfide mine wastes. Mineralogical Association of Canada Waterloo, Ontario, pp 438

Jambor JL, Blowes DW (1998) Theory and applications of mineralogy in environmental studies of sulfide-bearing mine wastes. In: Cabri LJ, Vaughan DJ (eds) Modern approaches to ore and environmental mineralogy. Mineralogical Association of Canada Short Course Series 27, pp 367-401
Jambor JL, Blowes DW, Ptacek CJ (2000) Mineralogy of mine wastes and strategies for remediation. In: Vaughan DJ, Wogelius RA (eds) Environmental mineralogy, EMU Notes in mineralogy. European Mineralogical Union, Eotvos University Press, Budapest, pp 255-290

Jeong GY, Lee BY (2003) Secondary mineralogy and microtextures of weathered sulfides and manganoan carbonates in mine wasterock dumps, with implications for heavy-metal fixation. Am Mineral 88:1933-1942

Kretz R (1983) Symbols for rock-forming minerals. Am Mineral 68:277-279

Marescotti P, Carbone C (2003) La miniera dismessa di Libiola (Sestri Levante, Liguria Orientale): studio mineralogico sui processi di alterazione di solfuri di $\mathrm{Fe}$ e $\mathrm{Cu}$ e valutazione del loro impatto ambientale. GEAM 109(3):45-53

Marini L, Saldi G, Cipolli F, Ottonello G, Vetuschi Zuccolini M (2003) Geochemistry of water discharges from the Libiola mine, Italy. Geochem J 37(2):199-216

Pratt AR, Nesbitt HW, Muir IJ (1994) Generation of acids from mine waste: oxidative leaching of pyrrothite in diluted $\mathrm{H}_{2} \mathrm{SO}_{4}$ solutions at $\mathrm{pH}$ 3.0. Geochim Cosmochim Acta 58:5147-5159

Provincia di Genova (2002) (Technical and Normative Document Approved with Legislative Decree 68/02) Piano di bacino, stralcio sul rischio idrogeologico. Torrente Gromolo, pp 133

Schwertmann U, Friedl J, Stanjek H (1999) From Fe(III) ions from ferrihydrite and then hematite. J Colloid Interface Sci 209:215223

Sobek AA, Schuller WA, Freeman JR, Smith RM (1978) Field and laboratory methods applicable to overburdens and minesoils. U.S. Environmental Protection Agency, EPA-600/2-78-054, Cincinnati, pp 47-50

Soregaroli BA, Lawrence RW (1997) Waste rock characterization at Dublin Gulch: a case study. Proceedings of the 4th international conference on acid rock drainage, Vancouver, pp 631-645 